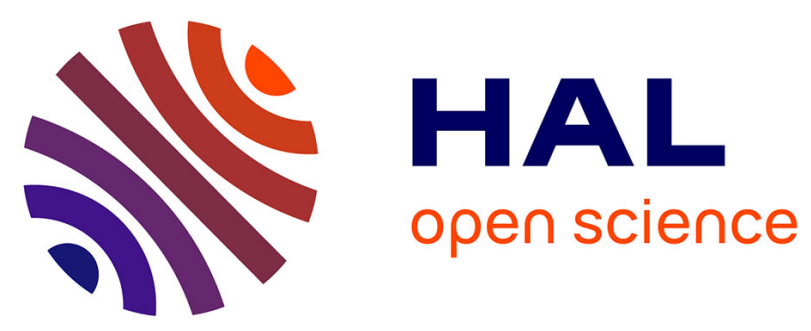

\title{
Response to commentary by Drs. Poncet and Sénéchal
}

Caroline Klingebiel, Yannick Chantran, Pascal Demoly, Davide Caimmi, Joëlle Birnbaum, Pol-André Apoil, Davide Paolo Caimmi, Marion Gouitaa, Isabelle Cabon-boudard, Stéphane Guez, et al.

\section{- To cite this version:}

Caroline Klingebiel, Yannick Chantran, Pascal Demoly, Davide Caimmi, Joëlle Birnbaum, et al.. Response to commentary by Drs. Poncet and Sénéchal. Clinical and Experimental Allergy, 2019, 00, pp.1 - 2. 10.1111/cea.13441 . hal-02159059

\section{HAL Id: hal-02159059 \\ https://hal-amu.archives-ouvertes.fr/hal-02159059}

Submitted on 18 Jun 2019

HAL is a multi-disciplinary open access archive for the deposit and dissemination of scientific research documents, whether they are published or not. The documents may come from teaching and research institutions in France or abroad, or from public or private research centers.
L'archive ouverte pluridisciplinaire HAL, est destinée au dépôt et à la diffusion de documents scientifiques de niveau recherche, publiés ou non, émanant des établissements d'enseignement et de recherche français ou étrangers, des laboratoires publics ou privés. 


\section{Response to commentary by Drs. Poncet and Sénéchal}

To the Editor

We thank Drs. Poncet and Sénéchal for their interest and critical reading of our paper. We are well aware of their pioneering work on molecular aspects of cypress pollinosis. However, the focus of our paper was rather on epidemiological, clinical and diagnostic features of peach allergy and not towards molecular pollen determinants.

We hereby provide answers to direct questions and notions made by Drs. Poncet and Sénéchal.

1. In regard to literature references, we cited those we found relevant for the scope and purpose of the paper and none of the three reviewers suggested citation of additional publications.

To our knowledge, the paper by Hugues et al (2006) was indeed the first to report an association between cypress and peach allergy, and it is cited as reference 39 in our paper ${ }^{1}$. However, contrary to the assertion by Poncet and Sénéchal, the authors of that paper did not identify a pollen homologue of Pru $\mathrm{p} 7$, which was first reported as an allergen by Tuppo et al in $2013^{2}$ but instead made the notion "Because both allergenic extracts include a $45 \mathrm{kDa}$-allergen, it should be the shared allergen." Cup a 1, a major allergen in cypress pollen, has a molecular weight of $43 \mathrm{kDa}$.

Experimental data from the Poncet team are currently available for BP14 and snakin-1, neither of which have been officially recognized and named as allergens by the WHO/IUIS Allergen Nomenclature Sub-Committee (www.allergen.org, accessed May 4 2019).

Other papers cited by Poncet et al are either replies or reviews. We prefer citation of original, peer-reviewed research. However, the review on cypress pollinosis is also cited in our paper as ref $41 .^{3}$

2. This case report of one patient with discordant FABER IgE and BAT results would have brought little if any further information to the reader. In our hands, the FABER test displays highly sensitive detection of IgE to Pru $p 7$.

3. As noted above, BP14 has not been officially recognized as an allergen.

4. Snakin-1 is out of the scope of our publication.

5. Recombinant Pru p 7 was biochemically and immunologically characterized as described in section $2.6^{4}$ and additionally by circular dichroism spectroscopy, but, given the focus of the paper, we did not consider it relevant to show and elaborate on such data, nor was there space available. It was also not suggested by any of the three reviewers. However, the BAT results shown in Table S3 demonstrate a similar functional potency of natural and recombinant Pru $\mathrm{p} 7$ which suggests an authentic folding of the recombinant protein.

- We do not agree that assessment of anti-microbial activity of recombinant Pru p 7 and several of the other specifics mentioned would be necessary to validate the association between cypress pollen allergy and peach allergy as suggested (but not yet done in their publications) by Drs Poncet and Sénéchal.

o The cypress species used was Cupressus sempervirens.

o The pollen was extracted and clarified by standard methods. We did not consider total protein concentration to be informative in relation to the purpose of the experiment but chose instead to determine the potency of the extract by titrated inhibition of IgE binding to Pru p 7, as described in section 3.5. That potency determination guided the choice of inhibitor concentration in the single-point inhibitions shown in figure 5A. $15 \%(w / v)$ means a concentration corresponding to $15 \mathrm{~g}$ of pollen (dry weight) per $100 \mathrm{~mL}$ of liquid, a manner of expressing concentrations also used by Poncet et al in their papers.

o The specificity of inhibition with the pollen extract was ensured by a complete lack of inhibition of binding of dog dander specific IgE to dog dander ImmunoCAP (e5) and is further indicated by the lack of significant inhibition in some samples as shown in figure 5A. Had the inhibitory effect of the cypress pollen extract been due to unspecific blockade of IgE, no such results would have been obtained.

We hope that our response will provide sufficient clarity and explanation to the questions raised by Drs. Poncet and Sénéchal.

Caroline Klingebiel ${ }^{1}$

Yannick Chantran ${ }^{2,3}$

Pascal Demoly ${ }^{4,5}$

Pol-André Apoil ${ }^{6}$

Davide Paolo Caimmi ${ }^{4,5}$

Joëlle Birnbaum $^{7}$

Marion Gouitaa ${ }^{8}$

Isabelle Cabon-Boudard ${ }^{9}$ Stéphane Guez ${ }^{10}$

Jean-Luc Bourrain ${ }^{4}$

Sylvie Leroy ${ }^{11,12}$

Thierry Bourrier ${ }^{13}$

Agnès Aferiat-Derome ${ }^{14}$

Anne Sarrat ${ }^{15}$ 


$$
\begin{gathered}
\text { Jonas Lidholm }^{16} \\
\text { Joana Vitte }
\end{gathered}
$$

${ }^{1}$ Laboratoire Synlab Provence, Marseille, France

${ }^{2}$ Sorbonne Universités, UPMC Univ Paris 06, INSERM UMRS

938, Centre de Recherche Saint-Antoine, team Immune System,

Neuroinflammation and Neurodegenerative Diseases, Paris, France

${ }^{3}$ Immunology Department, AP-HP Saint-Antoine Hospital, Paris, France

${ }^{4} \mathrm{CHU}$ Montpellier, Hôpital Arnaud-de-Villeneuve, Département de

pneumologie et addictologie, Univ Montpellier, Montpellier, France

5INSERM UMRS 1136, IPLESP, team EPAR, Sorbonne Universités, Paris,

France

${ }^{6}$ Institut Fédératif de Biologie, Hôpital Purpan, CHU Toulouse, Toulouse,

France

${ }^{7}$ Service de Pneumologie et Allergologie, $\mathrm{CH}$ du Pays d'Aix, Aix-en-

Provence, France

${ }^{8}$ APHM, Hôpital Nord, Service de Pneumologie, Aix-Marseille Univ, Marseille, France

${ }^{9}$ APHM, Hôpital Timone, Service de Chirurgie pédiatrique, Aix-Marseille Univ, Marseille, France

${ }^{10}$ Médecine Interne et Post-Urgences, Unité des Maladies Allergiques, GH Pellegrin, CHU Bordeaux, Bordeaux, France

${ }^{11}$ Service de Pneumologie, Hôpital Pasteur, CHU Nice, Nice, France

${ }^{12}$ CNRS UMR 7275-Institut de Pharmacologie Moléculaire et Cellulaire, Université de Nice Sophia Antipolis, Nice, France ${ }^{13}$ Hôpitaux pédiatriques de Nice, CHU Lenval, Nice, France

${ }^{14}$ Medical office, Les Jardins de Castellane, Marseille, France

${ }^{15}$ Laboratoire d'Immunologie et Immunogénétique, GH Pellegrin, CHU Bordeaux, Bordeaux, France
${ }^{16}$ Thermo Fisher Scientific, Uppsala, Sweden

${ }^{17} I R D, A P H M, M E P H I$, IHU Méditerranée Infection, Aix-Marseille Univ,

Marseille, France

Correspondence

Joana Vitte, Aix-Marseille Univ, IRD, APHM, MEPHI, IHU Méditerranée Infection, Marseille, France.

Email: jvitte@ap-hm.fr

\section{ORCID}

Joana Vitte iD https://orcid.org/0000-0002-3344-9408

\section{REFERENCES}

1. Hugues B, Didierlaurent A, Charpin D. Cross-reactivity between cypress pollen and peach: a report of seven cases. Allergy. 2006;61:1241-3.

2. Tuppo L, Alessandri C, Pomponi D, Picone D, Tamburrini M, Ferrara R, et al. Peamaclein - A new peach allergenic protein: similarities, differences and misleading features compared to Pru p 3. Clin Exp Allergy. 2013;43:128-40.

3. Charpin D, Pichot C, Belmonte J, Sutra JP, Zidkova J, Chanez P, et al. Cypress pollinosis : from tree to clinic. Clin Rev Allergy Immunol. 2019;56:174-95.

4. Klingebiel $C$, Chantran $Y$, Arif-Lusson R, Ehrenberg AE, Östling $J$, Poisson A, et al. Pru p 7 sensitization is a predominant cause of severe, cypress pollen-associated peach allergy. Clin Exp Allergy. 2019;49:526-36. 